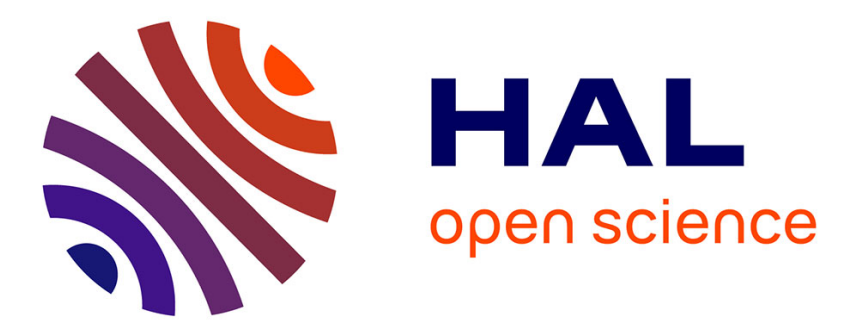

\title{
, an emerging pathogen for salmonid culture
}

Jesús L. Romalde, Carmen Ravelo, Iván Valdés, Beatriz Magariños, Eduardo de La Fuente, Carolina San Martín, Rubén Avendaño-Herrera, Alicia E.

Toranzo

\section{- To cite this version:}

Jesús L. Romalde, Carmen Ravelo, Iván Valdés, Beatriz Magariños, Eduardo de La Fuente, et al.. , an emerging pathogen for salmonid culture. Veterinary Microbiology, 2008, 130 (1-2), pp.198. 10.1016/j.vetmic.2007.12.021 . hal-00532381

\section{HAL Id: hal-00532381 https://hal.science/hal-00532381}

Submitted on 4 Nov 2010

HAL is a multi-disciplinary open access archive for the deposit and dissemination of scientific research documents, whether they are published or not. The documents may come from teaching and research institutions in France or abroad, or from public or private research centers.
L'archive ouverte pluridisciplinaire HAL, est destinée au dépôt et à la diffusion de documents scientifiques de niveau recherche, publiés ou non, émanant des établissements d'enseignement et de recherche français ou étrangers, des laboratoires publics ou privés. 


\section{Accepted Manuscript}

Title: Streptococcus phocae, an emerging pathogen for salmonid culture

Authors: Jesús L. Romalde, Carmen Ravelo, Iván Valdés, Beatriz Magariños, Eduardo de la Fuente, Carolina San Martín, Rubén Avendaño-Herrera, Alicia E. Toranzo

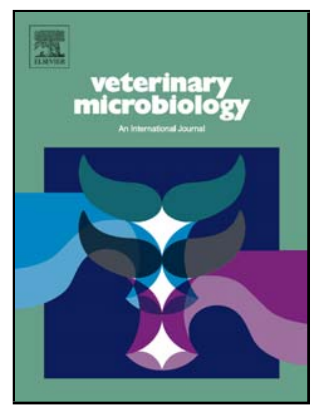

PII:

DOI:

S0378-1135(07)00644-X

Reference: doi:10.1016/j.vetmic.2007.12.021

To appear in: $\quad$ VETMIC

Received date: $\quad$ 25-6-2007

Revised date: $\quad 12-12-2007$

Accepted date: $\quad$ 13-12-2007

Please cite this article as: Romalde, J.L., Ravelo, C., Valdés, I., Magariños, B., de la Fuente, E., Martín, C.S., Avendaño-Herrera, R., Toranzo, A.E., Streptococcus phocae, an emerging pathogen for salmonid culture, Veterinary Microbiology (2007), doi:10.1016/j.vetmic.2007.12.021

This is a PDF file of an unedited manuscript that has been accepted for publication. As a service to our customers we are providing this early version of the manuscript. The manuscript will undergo copyediting, typesetting, and review of the resulting proof before it is published in its final form. Please note that during the production process errors may be discovered which could affect the content, and all legal disclaimers that apply to the journal pertain. 
Streptococcus phocae, AN EMERGING PATHOGEN FOR SALMONID

4

Jesús L. Romalde ${ }^{1 *}$, Carmen Ravelo $^{1} \dagger$, Iván Valdés ${ }^{2}$, Beatriz Magariños ${ }^{1}$,

6 Eduardo de la Fuente ${ }^{3}$, Carolina San Martín ${ }^{4}$, Rubén Avendaño-Herrera ${ }^{2}$ and

$7 \quad$ Alicia E. Toranzo 1

8

$9 \quad{ }^{1}$ Departamento de Microbiología y Parasitología. Facultad de Biología. Universidad 10 de Santiago de Compostela. 15782, Santiago de Compostela. Spain.

$11{ }^{2}$ Veterquímica. Laboratorio de Investigación y Desarrollo. Camino Melipilla 5641, 12 Cerrillos, Santiago. Chile.

$13{ }^{3}$ Aquatic Health Chile S.A.. Ruta 5 Sur, Km. 1013. Puerto Varas, Chile.

$14{ }^{4}$ Aquagestión. Fundación Chile. Panamericana Sur 581. Puerto Montt, Chile. 15

16 Submitted to: Veterinary Microbiology, December 2007.

17

18
Revised version Ms. VETMIC-D-07-1751 as Short Communication

* Corresponding author:

Phone: +34-981563100 \# 13253

Fax: +34-981596904

E-mail: mpromald@usc.es

$\dagger$ Present address:

Laboratorio de Ictiopatología. Estación de Investigaciones Hidrobiológicas de Guayana. Fundación La Salle de C.N. 8051, Ciudad Guayana. Venezuela. 


\section{Abstract}

This work describes the characterization of the causal agent of disease outbreaks that, from 1999, occurred repeatedly during the summer months (temperatures higher than $15^{\circ} \mathrm{C}$ ) in Atlantic salmon (Salmo salar) cage-farmed in Chile affecting both smolts and adult fish cultured in estuary and marine waters, reaching in some occasions a cumulative mortality up to $25 \%$ of the affected population. Diseased fish showed exophthalmia with accumulation of purulent and haemorrhagic fluid around eyes, and ventral petechial haemorrhages. At necropsy, haemorrhage in the abdominal fat, pericarditis, and enlarged liver, spleen and kidney are common pathological changes. Gram-stained smears revealed the presence of Gram-positive cocci, $\square$ eta-hemolytic, negative for oxidase and catalase tests. Although biochemical characterization of the isolates using the miniaturized system rapid ID 32 Strep suggested their assignation to genus Gemella, sequencing and RFLP analysis of the 16S rRNA revealed that bacteria associated with the mortalities belong to Streptococcus phocae. Serological studies demonstrated that all the salmon isolates are antigenically homogeneous, which can facilitate the development of preventive measures and, although sharing some antigenical determinants, they belong to a different Lancefield group than the type strain isolated from seals. On the basis of these facts, we conclude that the species $S$. phocae is an emerging pathogen for salmonid culture in Chile, and it should be included as a new member of the warm water streptococcosis.

Key words: Streptococcus phocae, Atlantic salmon, Emerging pathogen 


\section{Introduction}

Fish stretptococcosis, is currently considered as one of the main limiting factors in the aquaculture industry, due to the significant economic losses (higher than $\$ 150$ million) that these infections cause in different cultured fresh- and seawater fish species worldwide (Austin and Austin, 2007; Ringø and Gatesoupe, 1998; Romalde and Toranzo, 2005). The first description of a streptococcal infection causing rainbow trout (Oncorhynchus mykiss) mortalities dates from 1956 (Hoshina et al., 1958). Since then, the disease has increased its host range, including yellowtail (Seriola quinqueradiata), salmonids, Japanese eel (Anguilla japonica), tilapia (Oreochromis spp.), striped bass (Morone saxatilis) and turbot (Scophthalmus maximus), among others, as well as its geographical distribution (Austin and Austin, 2007; Ringø and Gatesoupe, 1998; Romalde and Toranzo, 2005).

There has been an important controversy about the number and the nature of the bacterial species involved with streptococcosis (Austin and Austin, 2007), probably due to the difficulty of an accurate identification at species level within this bacterial group when using conventional microbiological criteria. With the development of molecular taxonomic techniques, it was possible to more accurately determine the precise taxonomic status of many isolates. Currently, there is general acceptance of the division of streptococcosis into two forms according to the virulence of the agents involved at high or low temperatures (Ghittino, 1999). "Warm water" streptoccosis, causing mortalities at temperatures higher than $15^{\circ} \mathrm{C}$, typically involves species such as Lactococcus garvieae (synonym Enterococcus seriolicida), Streptococcus iniae (synonym S. shiloi), S. agalactieae (synonym $S$. difficilis) or $S$. parauberis. On the other hand, "cold water" streptococcosis is caused by Vagococcus salmoninarum or $L$. piscium and occurs at temperatures below $15^{\circ} \mathrm{C}$.

Streptococcus phocae, a beta-hemolytic streptococcal species, was first isolated from clinical specimens of harbor seal (Phoca vitulina) affected by pneumonia (Skaar et al., 2003). Further studies described isolations of this species from other marine mammals including Cape fur seal (Arctocephalus pusillus pusillus), ringed seal (Phoca hispida) and harbor porpoise (Phocoena phocoena) and gray seal (Halichoerus grypus) and cetaceans (Henton et al., 1999; Lawson et al., 2004; Raverty and Fiessel, 2001; Raverty et al., 2004; Vossen et al., 2004), associated in general to respiratory infections. 
85 In this paper, the biochemical, serological and genetic characterization of the 86 streptococcal strains isolated during several years from salmon showing septicemic disease is described. In addition, we present data on their implication in the appearance and progression of the disease in Chile from its first observation in 1999, the possible origins, as well as the clinical significance for the Chilean salmon industry.

\section{Materials and Methods}

Bacterial strains. A total of 34 strains isolated from internal organs (kidney, spleen or brain) or from ulcers of diseased cage-cultured Atlantic salmon in Chile were studied (Table 1). In addition, the type strain DSMZ 15635 of Streptococcus phocae, isolated from seal in Norway, was also analyzed for comparison. The bacteria were routinely grown on Columbia sheep blood agar (CBA)(Oxoid Ltd., Basingstone, England) and on tryptone soy agar supplemented with 1\% $\mathrm{NaCl}$ (TSA-1) (Difco Laboratoires, Detroit, Mich.) under aerobic conditions at $22-25^{\circ} \mathrm{C}$ for $48 \mathrm{~h}$. Stock cultures were maintained frozen at $-70^{\circ} \mathrm{C}$ in criobille tubes (AES Lab., France) or in tryptone soy broth (TSB-1) with 15\% glycerol.

Phenotypic tests. All the strains were subjected to taxonomical analysis by standard morphological, physiological, and biochemical plate and tube tests (Facklam, 2002; McFaddin, 1983; Schleifer, 1986). The ability of the strains to grow at 4, 10, 25, 30 and $37^{\circ} \mathrm{C}$ was tested in TSA- 1 over a period of 10 days. Growth at different salinities was determined in basal medium (neopeptone $4 \mathrm{~g} / \mathrm{L}$, yeast extract $1 \mathrm{~g} / \mathrm{L}$, agar $15 \mathrm{~g} / \mathrm{L}$ ) supplemented $0,0.5,3,6.5$ and $8 \% \mathrm{NaCl}$ after 1 week incubation.

The commercial Rapid ID 32 Strep and API ZYM miniaturized systems (bioMeriux, Madrid, Spain) were used following the manufacturer's instructions except for the temperature of incubation which was set at $25^{\circ} \mathrm{C}$. Standardized inocula were prepared by suspending cells in tubes containing sterile distilled water and adjusted spectrophotometrically to D.O of 1.0 ( $\left.\mathrm{A}_{580}\right)$ (Ravelo et al., 2001).

The drug sensitivities of the strains were determined by the disc diffusion method on Muller-Hinton agar (Oxoid) with $1 \% \mathrm{NaCl}$. The following chemotherapeutic agents (micrograms per disc) were used: oxolinic acid (10), trimethoprim-sulfametoxazole (23.75/1.25), amoxycillin (25), oxytetracycline (30), erythromycin (15), and florfenicol (30). 


\section{Genetic characterization.}

119 Genetic characterization by sequencing of the 16S rRNA gene was also carried out.

120 Isolation of DNA from pure cultures was performed using the "Instagene" matrix

121 (Bio-Rad), following manufacturer's recommendations. 16S rRNA genes were

122 amplified by PCR with universal primers pA and pH (Hutson et al., 1993). Primers

123 (Funke et al., 1995) corresponding to internal conserved regions of this gene were

124 used for the sequencing reactions in an Eppendorf Mastercycler Personal (Eppendorf,

125 Germany), with the CEQ-Dye Terminator Cycle Sequencing Quick Start Kit

126 (Beckman Coulter, USA). Sequencing products were analyzed using a CEQ 8000

127 Sequencer (Beckman Coulter, USA). Comparative sequence analyses were conducted 128 using FASTA3 program. Sequences of the closest relatives were retrieved from Gene

129 bank/EMBL, and the alignments and phylogenetic analysis were performed by the

130 Neighbour-joining method using the ClustalX (Thompson et al., 1997). Bootstraps

131 were calculated with 1000 replications, and Streptococcus ferus (AY058218) was

132 used as out-group sequence. Phylogenetic tree was drawn using the software NJPlot

133 (Perrière and Gouy, 1996).

134 In addition, adscription of the salmon isolates to the species $S$. phocae was also 135 confirmed by restriction fragment length polymorphism (RFLP) analysis of the 16S 136 rRNA gene using the restriction enzymes EarI and HincII (BioLabs, Schalbach, 137 Germany) as described by Vossen et al. (2004).

\section{Serological assays}

139 Antiserum against the salmon isolate 2857 was prepared by intravenous injections of 140 rabbits with formalin-killed cells suspended in saline as previously described 141 (Magariños et al., 1992). This protocol was approved by the Ethics Committee for 142 Animal Experiments of the University of Santiago. Whole cell preparations of the 143 isolates were employed in all the serological assays performed. Slide agglutination 144 tests were conducted following the procedures of Toranzo et al. (1987) and the dot 145 blot assays were performed as described by Cipriano et al. (1985).

146 The Lancefield streptococcal grouping (Lancefield, 1933) for the fish isolates was 147 confirmed using Diagnostic Reagents (Oxoid Ltd., Basingstone, England) according 148 to the manufacturer's protocol. The strains Streptococcus agalactiae S/246 (serogroup 149 B), group G Streptococcus S/299 and Streptococcus mitis S/290 were included for 150 quality control in every test run and were grown as described above. These strains 151 were obtained from the Instituto de Salud Pública, Chile. 
152

153

154

155

156

157

158

159

160

161

162

163

164

165

166

167

168

169

170

171

172

173

174

175

176

177

178

179

180

181

182

183

184

185

\section{Virulence for fish and mice}

In order to determine the virulent capacities of the isolates, infectivity trials were conducted using different fish species and mice. Representative isolates (Au15, 2857, and C4) were intraperitoneally (i.p.) inoculated in Atlantic salmon (20 g) and rainbow trout $(15 \mathrm{~g})$. Prior to challenge, fish were randomly sampled to be subjected to microbiological analysis which indicated that they were free of $S$. phocae and other pathogens. Groups of 15 fishes were inoculated $(0.1 \mu 1)$ with different bacterial doses ranging from $10^{4}$ to $10^{9}$ cells/fish. Control fish received $0.1 \mu 1$ of saline solution $(0.85 \% \mathrm{NaCl})$. In addition, one group of 15 Atlantic salmon $(20 \mathrm{~g})$ was subcutaneously inoculated $(0.1 \mu \mathrm{l} /$ fish $)$ with of two doses $\left(10^{5}\right.$ and $10^{6}$ cells/fish $)$ of the isolate Au15. Fish were maintained in seawater tanks at $19 \pm 1^{\circ} \mathrm{C}$ with aeration during the course of the experiments (21 days) making a daily $50 \%$ water renovation. Fish mortality was daily checked during this period. Dead fish were microbiologically analyzed for re-isolation of the inoculated strain. The degree of virulence was expressed as lethal dose $50 \%\left(\mathrm{LD}_{50}\right)$ calculated as described by Reed and Müench (1938).

To determine the pathogenic potential for homoiotherm animals, a mouse virulence assay was performed including three isolates from Atlantic salmon and the $S$. phocae type strain DSMZ $15635^{\mathrm{T}}$. Briefly, groups of 5 BALB/C mice (10-12 weeks old, 21$25 \mathrm{~g})$ were inoculated i.p. with bacterial dose of $10^{7}$ cells $(0.1 \mu \mathrm{l} /$ mouse $)$. Mortalities were recorded daily during a period of 10 days. Strain CDC 2227-81 of Photobacterium damselae subsp. damselae, previously described as pathogenic for mice (Osorio et al., 2000) was included in the assay as positive control.

The Ethics Committee for Animal Experiments of the University of Santiago approved the protocols of this study.

\section{Results}

From 1999, disease outbreaks occurred repeatedly during the summer months (temperatures higher than $15^{\circ} \mathrm{C}$ ) in Atlantic salmon (Salmo salar) farmed in Chile affecting both smolts and adult fish cultured in floating cages in estuary and marine waters. The disease presents a rapid time course with appearance of clinical signs in 1 or 2 days, although in acute cases fish can not show any sympthom. Isolates studied in this work were isolated from 28 independent outbreaks, showing cumulative mortalities between 3 and $25 \%$ of the affected population. From its first appearance 
186 until 2003, the disease has only been detected in waters of the Reloncaví estuary (X 187 Chilean Region), being further spread to other Chilean Regions, in some cases

188

189

190

191

192

193

194

195

196

197

198

199

200

201

202

203

204

205

206

207

208

209

210

211

212

213

214

215

216

217

218

219 associated to fish with origin in Reloncaví but sold and transported as smolts.

Diseased fish showed exophthalmia with accumulation of purulent and haemorrhagic fluid around eyes, ventral petechial haemorrhages, skin abscesses and, in some cases, muscle liquefaction with formation of deep ulcerative areas (Fig. 1). At necropsy, haemorrhage in the abdominal fat, pericarditis with accumulation of a white fluid in the pericardic cavity, and enlarged liver (showing a yellowish colour), spleen and kidney are common pathological changes (Fig. 1). Gram-stained smears revealed the presence of Gram-positive cocci in all cases.

The microbiological analysis of internal organs (kidney, spleen and brain) and ulcers revealed the presence on $\mathrm{CBA}$, in pure culture or as major colony type, of pinpoint white colonies $(0.5 \mathrm{~mm}$ diameter). The isolated bacteria were Gram positive chainforming cocci (0.6-0.9 $\mu \mathrm{m}$ diameter), beta-haemolytic, negative for the catalase and aesculin hydrolysis tests, growing at 25 and $37^{\circ} \mathrm{C}$ and at $\mathrm{pH} 9.6$ but not with $6.5 \%$ $\mathrm{NaCl}$ or $40 \%$ bile salts. These results indicated that the bacteria could be assigned presumptively to the Genus Streptococcus.

When the miniaturized system Rapid ID 32 Strep was employed, 30 out of 34 Atlantic salmon isolates rendered the profile 04000000000 , showing a positive reaction only for the phosphatase alcaline test. Four strains rendered the same profile than the type strain, 04000001000, being positive also for the utilization of maltose. With both profiles, strains were classified according to the API database as belonging to the Genus Gemella (G. haemolysans or G. morbillorum). On the other hand, all the isolates and the type strain showed the same enzymatic patterns in the API ZYM system, being positive for the production of alkaline and acid phosphatases and leucine arylamidase.

All the isolates showed the same pattern of resistence/susceptibility to chemotherapeutic agents in vitro, being susceptible to amoxycillin, oxytetracycline, erythromycin and florfenicol and resistant to flumequine, oxolinic acid and trimethoprim-sulfametoxazole.

16 Sequencing analysis of the $16 \mathrm{~S}$ rRNA gene revealed that all the Atlantic salmon isolates studied were identical, and that the sequences obtained showed similarities higher than $98.18 \%$ with $S$. phocae (98.18 and $100 \%$ identity with sequences AF235052 and AJ621053, respectively)(Fig. 2). The next relatives were S. pyogenes 
220

221

222

223

224

225

226

227

228

229

230

231

232

233

234

235

236

237

238

239

240

241

242

243

244

245

246

247

248

249

250

251

252

and S. agalactiae with similarities slightly higher than 93\%. Moreover, in the RFLP analysis all the isolates rendered the expected fragments employing either HincII or EarI endonucleases. Restriction with the enzyme HincII restriction yielded two characteristic fragments with sizes of 180 and 1230 bp) (Fig. 3), whereas EarI rendered three DNA fragments with sizes of 170, 380, and 840 bp (data not shown). Serological studies using different techniques, such as slide agglutination and dot blot, with specific serum raised against the Atlantic salmon isolate 2857, demonstrated that all the salmon isolates are antigenically homogeneous, sharing antigenic determinants with the type strain isolated from seals (Table 1). However, when the commercial Lancefield streptococcal grouping kit was employed, the isolates from fish were classified as group $\mathrm{G}$, although showing also a weak cross-reactivity with serum from antigenic group A, while the type strain DSMZ $15635^{\mathrm{T}}$ was assigned to serogroup F.

The three isolates inoculated were pathogenic for Atlantic salmon with $\mathrm{LD}_{50}$ values ranging from $1.9 \times 10^{5}$ and $5.6 \times 10^{5}$ bacteria per fish but not for rainbow trout when i.p. inoculated. Mortalities began two days after inoculation, being observed a dramatical increase by day 6. No mortalities were observed in the control groups. Inoculated bacteria could be recovered from dead fish which showed in all cases the typical necrotic lesions observed in the natural outbreaks. On the other hand, subcutaneously inoculated salmon showed a gross inflammation in the injection area, which progressed to necrosis with caseous material and liquefaction. Mortalities started 4 days after inoculation reaching 80 and 100\% for the low and high dose respectively. None of the $S$. phocae isolates, including the type strain, were pathogenic for mice, being observed no mortalities during ten days. Three out of the 5 BALB/C mice inoculated with the strain of $P$. damselae subsp. damselae utilized as positive control, died during the same period.

\section{Discussion}

Streptococcus phocae, a member of the pyogenic streptococcal group (Köhler, 2007) has been described as an organism associated with disease and mortality of different seal species in Norway, German North and Baltic seas and South Africa (Henton et al., 1999; Skaar et al., 1994; Vossen et al., 2004). More recently Gibello et al. (2005), during the development of a PCR protocol for Streptococcus iniae, employed some streptococcal strains from the bacterial collection at the FRS marine Laboratory in 
253 Aberdeen, Scotland, originally isolated from Atlantic salmon in Chile which after

254 their genetic characterization were also assigned to the species $S$. phocae. These 255 authors indicated the necessity to determine the real clinical significance of this 256 bacterial species for the Chilean salmon industry. In this work, a collection of 34 257 strains of S. phocae isolated from diseased Atlantic salmon were biochemical, 258 serological and genetically characterized and data on the appearance and progression 259 of the disease in Chile from its first observation in 1999 were presented, in order to 260 get a better understanding of this pathology.

261 The taxonomical analysis of the Atlantic salmon isolates revealed a great 262 homogeneity, regardless the year of isolation or geographical area of origin, and that 263 they were nearly identical to the type strain of this bacterial species. Such 264 homogeneity has been previously described by other authors for $S$. phocae (Gibello et 265 al., 2005; Henton et al., 1999; Skaar et al., 1994; Vossen et al., 2004). Although the 266 preliminary characterization indicated their assignation to the genus Streptococcus, 267 when the miniaturized Rapid ID 32 Strep system was employed, the profiles obtained 268 corresponded to good identification of members of the genus Gemella, mainly $G$. 269 haemolysans. However, although it has been reported that differentiation of some 270 streptococcal groups and Gemella strains is not easy (Lee et al., 2004), these later 271 organisms are alpha-haemolytic Gram variable cocci forming pairs or tetrads, 272 properties completely different from those of the salmon isolates. Moreover, 273 misidentifications of $S$. phocae strains using this miniaturized system were also 274 reported by Gibello et al. (2005), although these authors observed profiles typical 275 from Gardnerella vaginalis. A reason for these misidentifications can be that $S$. 276 phocae is not included in the API Database, which is focused mainly in human 277 pathogens.

278 The development and application of molecular techniques have greatly facilitated the 279 identification and classification of streptococci (Bentley and Leigh, 1995; Romalde 280 and Toranzo, 2005; Täpp et al., 2003), having the advantages of time-saving and 281 accuracy. The use of molecular methods, such as sequencing or RFLP analysis of the 282 16S rRNA gene, in the identification of the Atlantic salmon isolates unequivocally 283 demonstrated that all of them belong to the species $S$. phocae.

284 Serological typing is an effective approach in the epidemiological study of various 285 Gram-positive bacteria. The results from the Lancefield typing, using reagents of the 
286 different antigenic groups, showed that the fish isolates could be assigned to antigenic 287 group G although displaying also a weak reaction with antiserum A. S. phocae strains 288 from seals have been described as belonging to Lancefield's groups C and F (Skaar et 289 al., 1994; Vossen et al., 2004). In fact, the reference strain (DSMZ $15635^{\mathrm{T}}$ ) from seal included in the study belonged to the Lancefield's group F. Therefore, the Atlantic salmon isolates represent a distinct serological group within $S$. phocae. On the other hand, all isolates, including the type strain, reacted with the antiserum raised in rabbit against the strain 2857, indicating the existence of some common antigenic components among salmon and seal isolates of $S$. phocae, probably in the cell envelope.

296 From the data obtained, it seems clear that movement of fish, in particular smolts, 297 between farms located in different geographical areas has played an important role in 298 the spreading of the diseased across Chile. More difficult is to find the origin for the first appearance of the disease in the Reloncaví estuary. We can speculate that a possible origin can be the numerous colonies of marine mammals present in these

301 Chilean regions (Schlatter and Hucke-Gaete, 1999; Sielfeld, 1999). Marine mammals 302 capture cultured salmon through the cage nets, and also cause a great stress with 303 subsequent apetite losses and high susceptibility to diseases (Arnold, 1992). Further 304 studies are needed to confirm this hypothesis.

305 Although some chemotherapeutants were effective in vitro, oral treatments with 306 oxytetracycline (80-120 mg/kg fish for $15-20$ days), erythromycin (50-70 mg/kg fish 307 for 7-14 days) or florfenicol (15-20 mg/kg fish for 15 days) reduced mortalities only 308 in part and during the treatment period when applied in the fish farms. The low 309 efficacy of the chemotherapy in controlling this streptococcal disease in Atlantic 310 salmon has led to an effort in developing preventive measures, including the use of 311 auto-vaccines which together with an early detection of clinical signs, maintenance of 312 fish at low densities, cleaning of the cage nets, etc., helped to decrease the impact of 313 S. phocae in the cultured fish.

314 In summary, and on the basis of the facts presented, we conclude that the species $S$. 315 phocae is an emerging pathogen for salmonid culture in Chile, and it should be 316 included as a new member of the warm water streptococcal syndrome. 
320 Nucleotide sequence accession number.

321 The nucleotide sequence corresponding to the 16S rRNA gene of S. phocae 2857 was

322 deposited in the GenBank/EMBL Database as representative of the Atlantic salmon 323 isolates, and it has been assigned the accession number EF599165.

324

325 Acknowledgements

326 Authors thank Alejandro Heisinger for his help in the obtention of some samples.

327 This work was supported in part by Grants AGL2003-09307-C02-01 and AGL2006328 13208-C02-01/ACU from the Ministerio de Educación y Ciencia (PDI MCyT). Spain. 329 
331

332

333

334

335

336

337

338

339

340

341

342

343

344

345

346

347

348

349

350

351

352

353

354

355

356

357

358

359

360

361

362

363

\section{References}

Arnold, H., 1992. Experimental predator control measures on marine salmon farms in Shetland. Submission to the Planning and Coordinating Committee of the Marine Mammal Action Plan, United Nations Environmental Programme, 25 pp.

Austin, B., Austin D.A., 2007. Bacterial fish pathogens. Diseases of farmed and wild fish. $4^{\text {th }}$ Ed. Springer/Prazis Publishing. Chichester.

Bentley, R.W., Leigh J.A., 1995. Development of PCR-based hybridization protocol for identification of streptococcal species. J. Clin. Microbiol. 33, 1296-1301.

Cipriano, R.C., Pyle, J.B., Starliper, C.E., Pyle S.W., 1985. Detection of Vibrio anguillarum antigen by the dot blot assay. J. Wildl. Dis. 21, 211-218.

Facklam, R., 2002. What happened to streptococci: overview of taxonomic and nomenclature changes. Clin. Microbiol. Rev. 15, 613-630.

Funke, G., C. P. Ramos, M. D. Collins., 1995. Identification of some clinical strains of CDC coryneform group A-3 and A-4 bacteria as Cellulomonas species and proposal of Cellulomonas hominis sp.nov. for some group A-3 strains. J. Clin. Microbiol. 33, 2091-2097.

Ghittino, C., 1999. La estreptococosis en los peces. Aquatic 2, art. 605. Available at URL http://aquatic.unizar.es/n2/art605/lact_rev.htm

Gibello, A., Mata, A.I., Blanco, M.M., Casamayor, A., Domínguez, L., FernándezGarayzabal, J., 2005. First identification of Streptococcus phocae isolated from Atlantic salmon (Salmo salar). J. Clin. Microbiol. 43, 526-527.

Henton, M.M., Zapke, O., Basson, P.A., 1999. Streptococcus phocae infection associated with starvation in Cape fur seals. J. S. Afr. Vet. Assoc. 2, 98-99.

Hoshina, T., Sano, T., Morimoto, Y., 1958. A Streptococcus pathogenic for fish. J. Tokyo Univ. Fisheries 44, 57-58.

Hutson, R.A., Thompson, D.E., Collins, M.D., 1993. Genetic interrelationships of saccharolytic Clostridium botulinum types B, E and F and related clostridia as revealed by small-subunit rRNA gene sequences. FEMS Microbiol. Lett. 108, 103 110.

Köhler, W., 2007. The present state of species within the genera Streptococcus and Enterococcus. Int. J. Med. Microbiol. 297, 133-150.

Lancefield, R.C., 1933. A serological differentiation of human and other groups of hemolytic streptococci. J. Exp. Med. 57, 571-595. 
364

365

366

367

368

369

370

371

372

373

374

375

376

377

378

379

380

381

382

383

384

385

386

387

388

389

390

391

392

393

394

395

396

397

Lawson, P.A., Foster, G., Falsen, E., Davison, N., Collins, M.D., 2004. Streptococcus halichoeri sp. nov., isolated from grey seals (Halichoerus grypus). Int. J. Syst. Evol. Microbiol. 54: 1753-1756.

Lee, M.R., Lee, S.-O., Kim, S.-Y., Yang, S.M., Seo, Y.-H., Cho, Y.K., 2004. Brain abscess due to Gemella haemolysans. J. Clin. Microbiol. 42, 2338-2340.

Magariños, B., Romalde, J.L., Bandín, I., Fouz B., Toranzo, A.E., 1992. Phenotypic, antigenic and molecular characterization of Pasteurella piscicida strains isolated from fish. Appl. Environ. Microbiol., 58, 3316-3322.

McFaddin, J.F., 1983 Biochemical test for identification of medical bacteria. $2^{\text {nd }}$ ed. Williams \& Wilkins, Baltimore. USA.

Osorio, C.R., Romalde, J.L., Barja J.L., Toranzo, A.E., 2000. Presence of phospholipase-D (dly) gene coding for damselysin production is not a pre-requisite for pathogenicity in Photobacterium damselae subsp. damselae. Microb. Pathogen., 28, 119-126.

Perrière, G., M. Gouy., 1996. WWW-query: an on-line retrieval system for biological sequence banks. Biochimie 78, 364-369.

Ravelo, C., Magariños, B., Toranzo, A.E., Romalde, J.L., 2001. Conventional versus miniaturized systems for the phenotypic characterization of Lactococcus garviaeae. Bull. Eur. Ass.Fish Pathol. 21, 136-144.

Raverty, S., Fiessel, W., 2001. Pneumonia in neonatal and juvenile harbor seals (Phoca vitulina) due to Streptococcus phocae. Animal Health Center. Newsletter. Diagn. Diary 11, 11-12.

Raverty, S., Gaydos, J.K., Nielsen, O., Ross, P., 2004. Pathologic and clinical implications of Streptococcus phoace isolated from pinnipeds along coastal Washington state, British Columbia, and Artic Canada. $35^{\text {th }}$ Annual Conference of the International Association of Aquatic Animal Medicine, Galveston, TX.

Reed, L.J., Müench, H., 1938. A simple method of estimating fifty percent end points. Amer. J. Hyg. 27, 493-497.

Ringø, E., Gatesoupe, F.-J., 1998. Lactic acid bacteria in fish: a review. Aquaculture 160, 177-203.

Romalde, J.L., Toranzo, A.E., 2002. Molecular approaches for the study and diagnosis of salmonid streptococcosis. In: Cunningham, C.C., (Ed), Molecular diagnosis of salmonid diseases. Kluwer Academic Publishers, Dordrecht. The Netherlands. pp: 211-233. 
398 Schlatter, R.R., Hucke-Gaete, R., 1999. Importance of international co-operation for

399 the conservation of Chilean seabirds and marine mammals. Estud. Oceanol. 18, 1340024.

401 Schleifer, K.H., 1986. Gram-positive cocci. In: Senath, P.H.A., Mair, N.S., Sharpe,

402 M.E., and Holt, J.G. (Eds.), Bergey's Manual of Systematic Bacteriology, Vol. 2.

403 Williams \& Wilkins, Baltimore. pp: 999-1103.

404 Sielfeld, W., 1999. The kowledge and conservation status of Otaria flavescens (Shaw, 405 1800) and Arctocephalus australis (Zimmermann, 1783) at the Chilean coasts. 406 Estud. Oceanol. 18, 81-96.

407 Skaar I, Gaustad P., Tonjum T., Holm B., Stenwig H., 1994. Streptococcus phocae sp. 408 nov., a new species isolated from clinical specimens from seals. Int. J. Syst. 409 Bacteriol. 44, 646-50.

410 Täpp, J., Thollesson, M., Herrmann, B., 2003. Phylogenetic relationships and 411 genotyping of the genus Streptococcus by sequence determination of the Rnase P 412 RNA gene, rnpB. Int. J. Syst. Evol. Microbiol. 53, 1861-1871.

413 Thompson, J.D., Gibson, T.J., Plewniak, F., Jeanmougin, F., Higgins, D.G., 1997. 414 The ClustalX windows interface: flexible strategies for multiple sequence alignment 415 aided by quality analysis tools. Nucl. Acids Res. 25,4876-4882.

416 Toranzo, A.E., Baya, A., Roberson, B.S., Barja, J.L., Grimes, D.J., Hetrick, F.M. 417 1987. Specificity of slide agglutination test for detecting bacterial fish pathogens. 418 Aquaculture 61, 81-97.

419 Vossen, A., Abdulmawjood, A., Lämmler, C., Weiß, R., Siebert, U., 2004. 420 Identification and molecular characterization of beta-hemolytic streptococci isolated 421 from harbor seals (Phoca vitulina) and grey seals (Halichoerus grypus) of the 422 German north and Baltic seas. J. Clin. Microbiol. 42, 469-473. 
423

424

425

426

427

428

429

430

431

432

433

434

435

436

437

438

439

440

441

442

443

444

445

\section{Figure Legends}

Fig. 1.- Clinical signs observed in the diseases Atlantic salmon. a) hemorhages around the eye; b) ventral petechial haemorrhages; c) ventral skin abscesses; d) deep ulceras with muscle liquefation; e) pericarditis with accumulation of a white fluid (arrow) in the pericardic cavity; f) haemorrhage in the abdominal fat and cavity; g) enlarged liver and spleen.

Fig. 2.- Phylogenetic tree of $16 \mathrm{~S}$ rRNA sequence for the Atlantic salmon isolates and the type strains of the closest streptococci. Streptococcus ferus (AY058218) was employed as outgroup. Horizontal branch lengths are proportional to evolutionary divergence. Significant brootstrap values of 1000 replicates appear next tyo the corresponding branch. The bar represents $1 \%$ sequence divergence. Sequences from relative species were obtained from GeneBank Database, and their accesion numbers are indicated after the species name.

Fig. 3.- Restriction of the amplified 16S rRNA gene with endocnuclease HincII. Lanes: M, molecular size marker (50-2000 ladder; Sigma); 1 and 2, amplicon and correspondent restriction from S. phocae DSMZ $15635^{\mathrm{T}} ; 3$ to 7 , amplicons and correspondent restrictions from Atlantic salmon isolates 2857, C-4 and PF-157, respectively. Numbers on the left indicate the position of molecular size marker in bp. Numbers on the right indicate the size of the specific amplified products and restriction fragments in $\mathrm{bp}$. 
446 447

448

449

450

451

452

453

454

455

456

457

458

459

$460 \quad 751$

$461 \quad 2880$

$462 \quad 5070$

463 C-4

464 Au11

465 Au13

466 Au14

$467 \quad$ Au15

468 PF-132

469 PF-133

$470 \quad$ PF-136

$471 \quad \mathrm{PF}-137$

472 PF-140

473 PF-142

$474 \quad$ PF-143

475 PF-145

476 PF-146

$477 \quad$ PF-148

478 PF-153

$479 \quad \mathrm{PF}-155$

$480 \quad$ PF-030

$481 \quad \mathrm{PF}-056$

$482 \quad \mathrm{PF}-058$

$483 \quad$ PF-059

$484 \quad$ PF-134

$485 \quad$ PF-157

\section{Origin}

Year of

Isolation $\underline{\text { Reaction with serum against }}$ isolate $\mathbf{2 8 5 7}$ Lancefield group

486 Reference strain

487 DSMZ $15635^{\mathrm{T}}$ Phoca vitulina, Norway

Reloncaví Estuary, Chile

Reloncaví Estuary, Chile

Reloncaví Estuary, Chile

Reloncaví Estuary, Chile

Reloncaví Estuary, Chile

Reloncaví Estuary, Chile

Reloncaví Estuary, Chile

Reloncaví Estuary, Chile

Reloncaví Estuary, Chile

Reloncaví Estuary, Chile

Reloncaví Estuary, Chile

Reloncaví Estuary, Chile

Herradura, Chile

Hualaihué, Chile

Reloncaví Bay, Chile

Curaco de Lin Lin, Chile

Chaitén, Chile

Herradura, Chile

Reloncaví Bay, Chile

Reloncaví Estuary, Chile

Calbuco, Chile

Comau Fiord, Chile

Reloncaví Estuary, Chile

Marimelli, Chile

Marimelli, Chile

Quillaipe, Chile

Quillaipe, Chile

Calbuco, Chile

Punta Venet, Chile

Castro, Chile

Castro, Chile

Castro, Chile

Chaitén Chile

Reloncaví Estuary, Chile
1999

1999

2001

2001

2001

2001

2002

2004

2004

2004

2004

2004

2004

2004

2004

2004

2004

2004

2004

2004

2004

2004

2004

2004

2004

2004

2004

2004

2005

2005

2005

2005

2005

2005
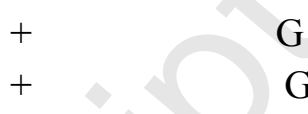

$+\mathrm{G}$

$+\quad \mathrm{G}$

$+\quad \mathrm{G}$

$+\mathrm{G}$

$+\quad \mathrm{G}$

$+\quad \mathrm{G}$

$+\quad \mathrm{G}$

$+\quad \mathrm{G}$

$+\quad \mathrm{G}$

$+\mathrm{G}$

$+\quad \mathrm{G}$

$+\mathrm{G}$

$+\quad \mathrm{G}$

$+\mathrm{G}$

$+\mathrm{G}$

$+\quad \mathrm{G}$

$+\quad \mathrm{G}$

$+\mathrm{G}$

$+\mathrm{G}$

$+\quad \mathrm{G}$

$+\mathrm{G}$

$+\quad \mathrm{G}$

$+\mathrm{G}$

$+\mathrm{G}$

$+\quad \mathrm{G}$

$+\mathrm{G}$

$+\quad \mathrm{G}$

$+\mathrm{G}$

$+\mathrm{G}$

$+\quad \mathrm{G}$

$+\mathrm{G}$

$+\mathrm{G}$

488

1994

$+$

F 


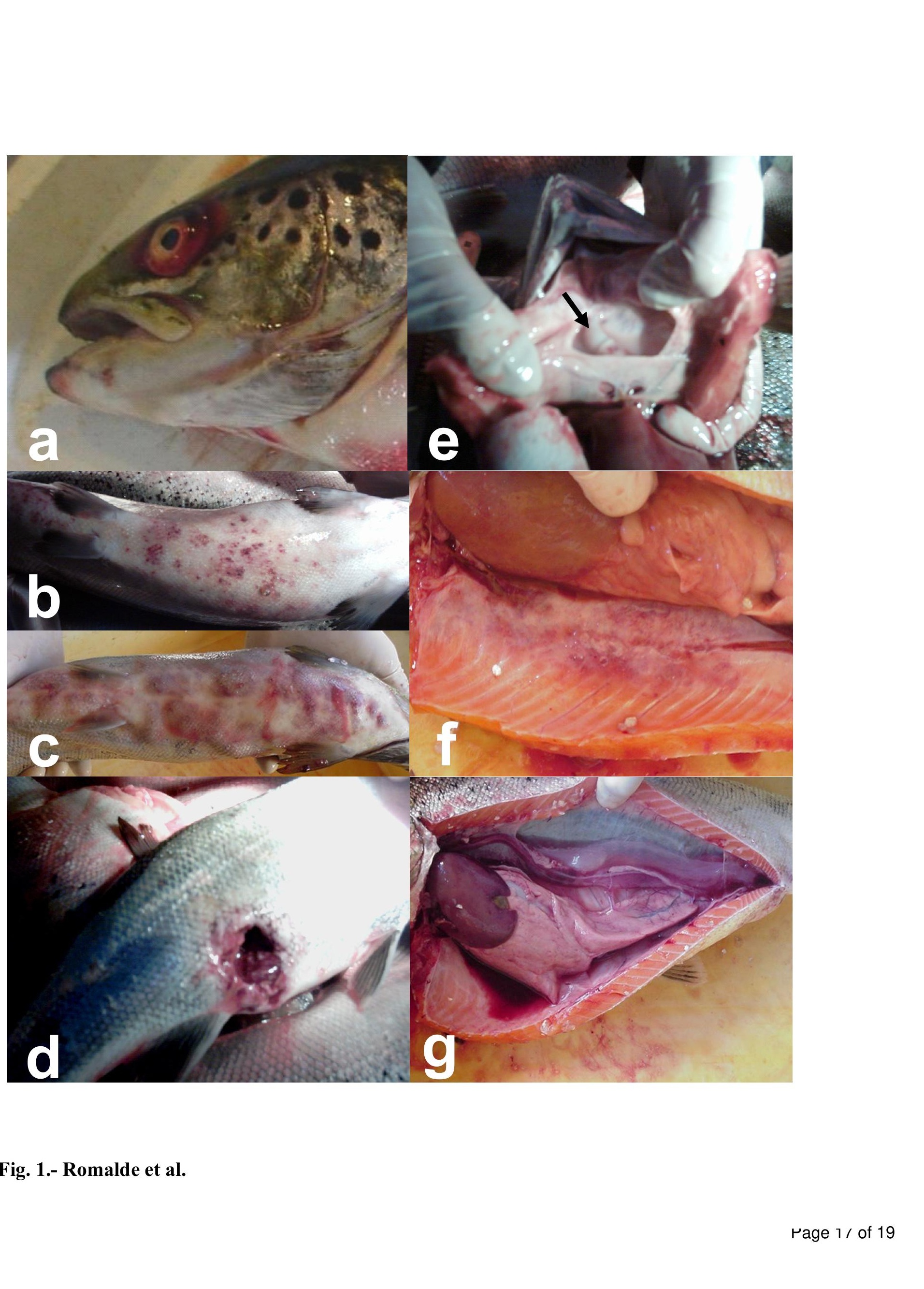

Fig. 1.- Romalde et al. Fig. 1

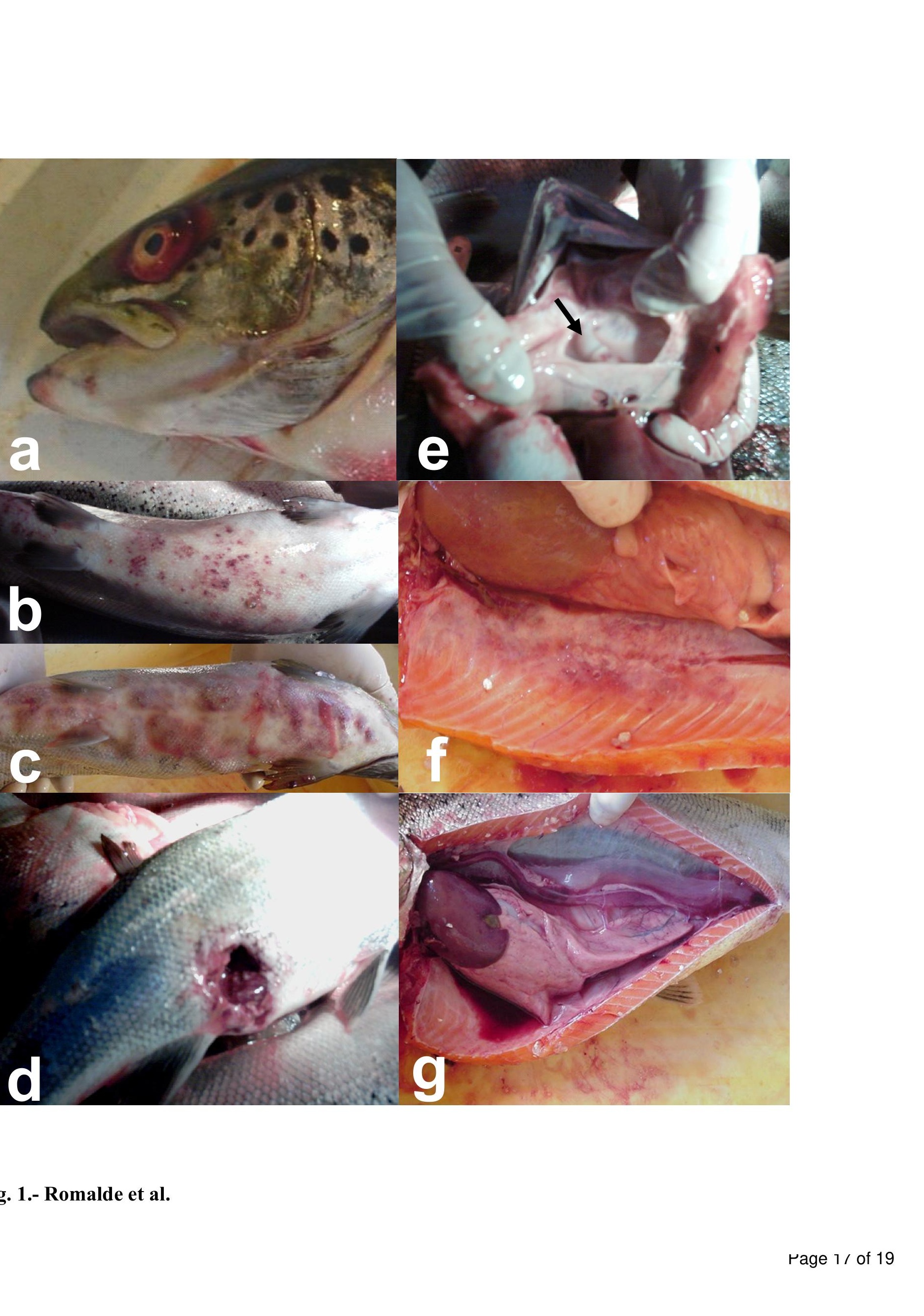




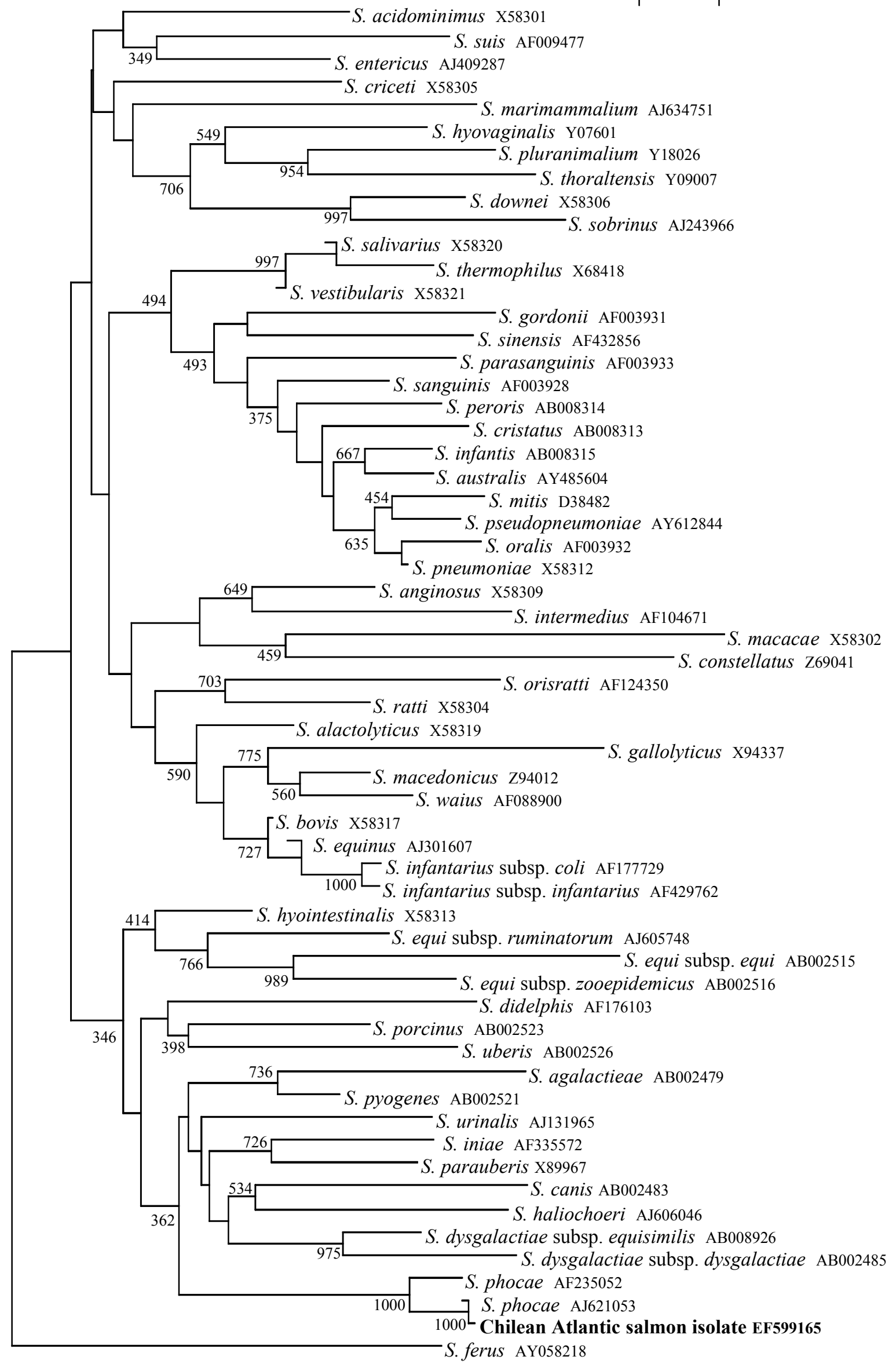

Fig. 2.- Romalde et al. 


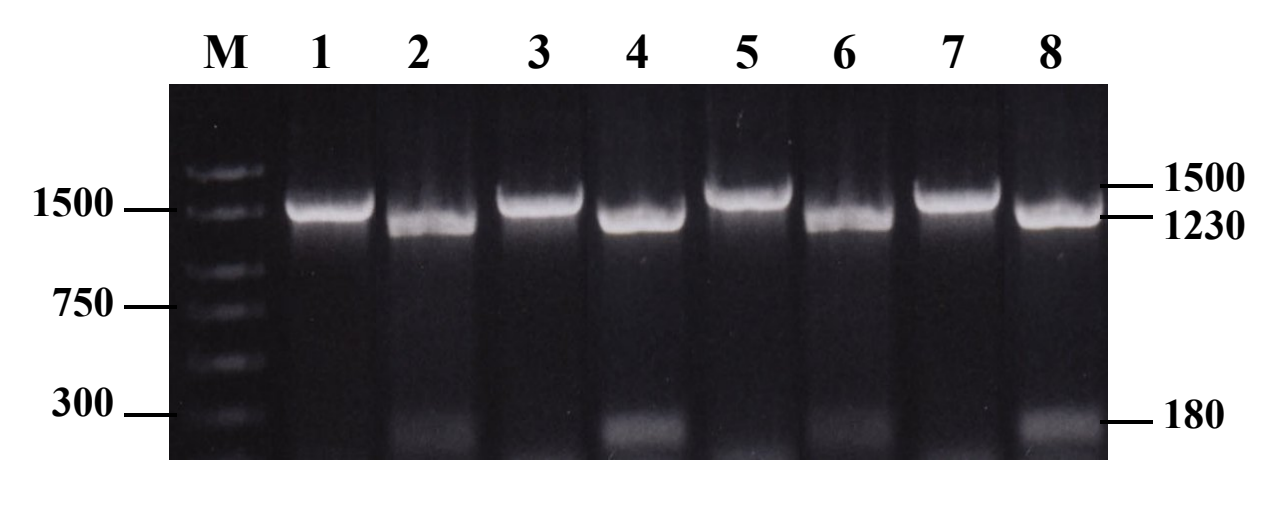

Fig. 3.- Romalde et al. 